\title{
Da iconoclastia à política das imagens: as aventuras da negatividade
}

\section{Márcio Seligmann-Silva'}

Resumo: O texto estuda as seguintes estações da iconoclastia e de suas mudanças: Antiguidade; Antigo Testamento; a querela iconoclasta medieval; Arnold Schönberg; S. Freud; Th. Adorno (a negatividade das imagens repensada a partir de uma nova ética da representação); W. Benjamin (o dever de destruição das falsas imagens da história); a virada testemunhal pós-colonial; o texto conclui com uma análise de obras de Jaime Lauriano, Alfredo Jaar e Rosana Paulino.

Palavras-chave: Querela Iconoclasta. Virada Pós-Colonial. Ética da Representação. Bildraum.

\section{From iconoclasm to the politics of images: the adventures of negativity}

\begin{abstract}
The text studies the following stations of iconoclasm and its changes: Antiquity; Old testament; the medieval iconoclastic quarrel; Arnold Schönberg; S. Freud; Th. Adorno (the negativity of images rethought from a new ethics of representation); W. Benjamin (the duty to destroy the false images of history); the postcolonial testimonial turn; the text concludes with an analysis of the works of Jaime Lauriano, Alfredo Jaar and Rosana Paulino.
\end{abstract}

Keywords: Iconoclastic Quarrel. Postcolonial Turn. Ethics Of Representation. Bildraum.

I Possui graduação em História pela Pontifícia Universidade Católica de São Paulo (1986), mestrado em Letras (Língua e Literatura Alemã) pela Universidade de São Paulo (1991), doutorado em Teoria Literária e Literatura Comparada pela Freie Universität Berlin (1996), pós-doutor pelo Zentrum Für Literaturforschung Berlim (2002) e por Yale (2006). Professor titular de Teoria Literária do Instituto de Estudos da Linguagem (IEL) da Universidade Estadual de Campinas (UNICAMP). Rua Sérgio Buarque de Holanda, n. 571 CEP 13083-859 - Campinas. E-mail: marcioseligmann@icloud.com. ORCID: https://orcid.org/0000-0001-9832-8415. Lattes iD: http://lattes.cnpq.br/4723569507970497. Campinas, São Paulo. 
Segundo uma narrativa tradicional, em 726 a imagem protetora de Constantinopla, o ícone de Cristo da Calcedônia, foi destruída pelo imperador Leão III, o Isauro (717-741) dando início a uma acirrada batalha entre iconófilos e iconoclastas. A imagem que figurava acima do pórtico de bronze do palácio imperial não seria digna de representar o filho de Deus. Independentemente desse fato ser real ou construído pela tradição (hipótese de Marie-France Auzépy, 1990), a verdade é que desde então por um século se estendeu essa batalha em torno das imagens e da representabilidade de Cristo/do Senhor. Tratou-se de uma batalha não só de ideias, mas que levou à destruição de muitas imagens embalada pelo "fervor belicoso" (Besançon 1997: 203) voltado à purificação do cristianismo.

Os iconoclastas, de resto, calcavam suas ideias e ações em uma leitura literal (hoje diríamos, fundamentalista) das palavras bíblicas. Recordemos algumas dessas passagens:

Não terás outros deuses além de mim. Não farás para ti nenhum ídolo, nenhuma imagem de qualquer coisa no céu, na terra, ou nas águas debaixo da terra. Não te prostrarás diante deles nem Ihes prestarás culto, porque eu, o Senhor, o teu Deus, sou Deus zeloso, que castigo os filhos pelos pecados de seus pais até a terceira e quarta geração daqueles que me desprezam, mas trato com bondade até mil gerações aos que me amam e obedecem aos meus mandamentos. (Ex. 20, 3-6)

[Deus a Moisés] "Você não poderá ver a minha face, porque ninguém poderá ver-me e continuar vivo". (Ex. 33, 20) "Não faça ídolos de metal para você." (Ex. 34, 17)

Então o Senhor falou a vocês do meio do fogo. Vocês ouviram as palavras, mas não viram forma alguma; apenas se ouvia a voz. (Dt. 4, 12) "Estes são os decretos e ordenanças que vocês devem ter o cuidado de cumprir enquanto viverem na terra que o Senhor, o Deus dos seus antepassados, deu a vocês como herança. Destruam completamente todos os lugares nos quais as nações que vocês estão desalojando adoram os seus deuses, tanto nos altos montes como nas colinas e à sombra de toda árvore frondosa. Derrubem os seus altares, esmigalhem as suas colunas sagradas e queimem os seus postes sagrados; despedacem os ídolos dos seus deuses e eliminem os nomes deles daqueles lugares. (Dt. 12, 1-5) “'Maldito quem esculpir uma imagem ou fizer um ídolo fundido, obra de artesãos, de-
testável ao Senhor, e levantá-lo secretamente'. Todo o povo dirá: 'Amém!' (Dt. 27, 15)

Não façam ídolos, nem imagens, nem colunas sagradas para vocês, e não coloquem nenhuma pedra esculpida em sua terra para curvar-se diante dela. Eu sou o Senhor, o Deus de vocês. (Le 26, 1)

"Assim diz o Senhor, o rei de Israel, o seu redentor, o Senhor dos Exércitos: Eu sou o primeiro e eu sou o último; além de mim não há Deus. [...] Há outro Deus além de mim? Não, não existe nenhuma outra Rocha; não conheço nenhuma". Todos os que 
fazem imagens nada são, e as coisas que estimam são sem valor. As suas testemunhas nada veem e nada sabem, para que sejam envergonhados. Quem é que modela um deus e funde uma imagem, que de nada lhe serve? Todos os seus companheiros serão envergonhados; pois os artesãos não passam de homens. (Is. 44, 6-17)

Tanto o deus bíblico se apresenta como sem-imagem (ou como uma hiper-imagem fatal, que aniquila quem a vê, inacessível aos humanos), para cuja representação nada é suficientemente digno, como também Ele é apenas nome. E ainda, trata-se de um Deus colonizador, que teme a competição de outros deuses e imagens. Ele quer o monopólio da devoção para si.

Quase mil e trezentos anos após essa querela iconoclasta, no ano de 2020, em meio à pandemia de Corona Vírus, como resposta ao brutal assassinato de George Floyd em 25/05 em Mineápolis, assassinado por asfixia por um policial branco, uma onda de ataques e destruições de monumentos que homenageiam a empresa colonial foi iniciada e incendeia até hoje o nosso cotidiano político-cultural. Caíram ou foram atacadas estátuas de traficantes de escravizados, monumentos a supostos descobridores de continentes e foram depostos reis imperiais sanguinários que estavam sobre os pedestais no centro de praças. Não se trata agora da oposição entre iconoclastas e iconolátricos, mas, antes, do confronto entre os admiradores de diferentes imagens. Essa guerra de imagens é uma guerra por narrativas que estão na base da construção de visões de mundo que nos atravessam e sustentam as nossas ações e nosso próprio estar no mundo.

Mas antes dessa batalha de imagens, que ainda segue enquanto escrevo estas palavras, desde a Segunda Guerra Mundial o campo das artes e da literatura foi assombrado por outro debate: refiro-me à questão da representabilidade e dos modos de apresentação da Shoah. Aqui o tema da imago dei foi radicalmente deslocado para a questão da imagem da dor e do sofrimento. Adorno abriu esse debate com uma frase de seu ensaio "Crítica cultural e sociedade", de 1949, que ficou famosa:

A crítica cultural defronta-se com o último degrau da dialética entre a cultura e a barbárie: é barbárie escrever um poema depois de Auschwitz, e isso também corrói o conhecimento que afirma por que hoje se tornou impossível escrever poemas. Enquanto o espírito crítico permanecer em si mesmo, em auto-suficiente contemplação, ele não será capaz de enfrentar a absoluta reificação que, entre os seus pressupostos, teve o progresso do espírito como um dos seus elementos e que hoje se prepara para suga-lo completamente. (Adorno 2001: 91) 
Adorno, como veremos, depois dedicou muitas páginas para explicar essa passagem, mas de certo modo nunca deixou de defender esse elemento iconoclasta, que ele só fez matizar em outros de seus decretos filosóficos. Se no século VIII era a desmesura divina que impedia a sua representação, agora é a desmesura da dor, da ignomínia, da violência genocida que bloqueia a construção de imagens.

Proponho-me neste texto fazer esse percurso, da Antiguidade à contemporaneidade, para refletir sobre o estatuto da atual querela de imagens por que passamos. Veremos como nossa atual batalha não nasceu no ano passado, mas apenas teve no brutal assassinato de Floyd um desencadeador de um movimento que já se dava, na verdade há séculos, dentro da modernidade. Para essa reflexão lançarei mão, ao final do percurso, da apresentação, mesmo que breve, de obras de três artistas que me parecem bastante representativos de nosso presente: Rosana Paulino, Jaime Lauriano e Alfredo Jaar.

\section{A querela iconoclasta medieval}

Para além das guerras entre gerações de faraós e seus deuses no Egito antigo (que levou, por exemplo, à tentativa de apagamento das imagens do faraó monoteísta Aquenáton e de seu deus Aton), e da instituição da damnatio memoriae da Antiguidade romana (que condenou ao esquecimento personalidades e suas estátuas, como Calígula e Nero), acho mais rico em consequências para meus objetivos estabelecer como primeira estação desta reflexão sobre a iconoclastia seu capítulo medieval. Mas para adentrar esse universo cristão, inicio com uma menção à doutrina cabalista judaica do Nome de deus. Ela desdobra a teologia negativa que lemos acima nas citações extraídas do antigo Testamento. Como observou Gershon Scholem, em seu ensaio "O nome de Deus e a teoria da linguagem cabalista":

\footnotetext{
A verdade, no sentido que o judaísmo foi o primeiro a dar à palavra Deus, era o acústico = linguisticamente perceptível. A Revelação, segundo o conceito didático da Sinagoga, é um processo acústico, não visual, ou algo ocorrido, no mínimo, numa esfera que está relacionada metafisicamente com o processo acústico, sensível. Esse fato é sempre de novo ressaltado no verbo da Torá (Deut. 4, 12): "Não vistes nenhuma imagem - apenas uma voz." (Scholem 1999: 9)
}

Scholem também destaca que para Abrahan Abuláfia, o grande cabalista de Zaragoza, do século XIII, o Nome de deus é totalmente desprovido de 
significação, é o "elemento para além do sentido" que "ao mesmo tempo, o possibilita". (1999: 60) Estamos, portanto, com essa doutrina mística da figura divina já em plena desautorização das imagens, ao menos das imagens visuais relativas a deus. A teologia negativa é avessa às imagens visuais, mas permite pensarmos em imagens acústicas para a divindade, ainda que o tetragrama YHWH seja a princípio impronunciável. O elemento acústico da percepção divina se revela também na oração central do judaísmo, o "Shemá Israel”, "Ouça Israel: O Senhor, o nosso Deus, é o único Senhor." (Deut. 6, 4-9).

As querelas iconoclastas foram alimentadas por essa tradição negativa, que se exacerbou com o islamismo e sua aversão à representação dos profetas que, apesar de não estar explicitada no Corão, foi rigorosamente praticada, com raras exceções. Da tradição clássica a Idade Média herdou também uma série de conceitos filosóficos, sobretudo (neo)platônicos, que permitiram associar a imagem ao culto enganoso de cópias. A metáfora da caverna que Platão desenvolve na República é um dos momentos mais claros dessa história negativa das imagens na Antiguidade. Nesse mito da caverna encontramos a humanidade amarrada diante de um espetáculo de sombras. Essa é uma das protocenas da metafísica ocidental e como ela se estrutura a partir do contraste e da diferença entre a luz e a sombra, verdade e imitação/ilusão. Nessa visão, a humanidade acorrentada vive na ilusão de ver a verdade, quando mira apenas sombras e escuta ecos. Os objetos que vê são sombras carregadas por fantoches. Um muro, nas costas da humanidade, a separa do mundo das formas originarias. Já aqui, portanto, vemos uma das imagens mais fortes na origem do preconceito contra tudo o que é derivado, segundo e simulação. Como nota Victor Stoichita, se nessa passagem as sombras são tratadas como phantasmata, em outra passagem da República, pouco anterior a essa imagem (alegoria ou mito) da caverna, Platão havia feito uma distinção do visível "segundo o grau de clareza e de obscuridade" afirmando: "Por imagens (eikona) entendo em primeiro lugar, sombras (skias), em seguida reflexos na água ( phantasmata) em todas as superfícies de textura densa, lisa e reluzente, e tudo desse gênero, se é que entendes." (Platão 509d-510a; Platão 2006: 304) Segundo Stoichita, para Platão são as sombras o "estágio mais distante com relação à verdade" (Stoichita, 2000, 25). Na teoria das artes como mímesis, na qual elas aparecem como cópias de cópias, na mesma República, podemos ver uma condenação da skiagraphia que, ainda segundo Stoichita, vale tanto para seu sentido de pintura de sombras, um simulacro, quanto para sua acepção como perspectiva, ou seja, ilusão mimética. Platão escreve: "é porque exploram essa debilidade de nossa natureza (pathêma) que a pintura enganosa [de sombras] (skiagraphia), a feitiçaria (thaumatopoia) e outras formas de prestidigitação têm 
poderes aos quais pouco falta de magia (goêteia)." (República 602d; Platão 2006: 430) Aqui já se une a crítica ao culto das imagens à condenação da veneração supersticiosa. Se nosso mundo é mera cópia, como Platão desenvolve na sua teoria das artes, o artista está afastado em um grau a mais da luz originária, seu trabalho é cópia da cópia.

Apesar dessas poderosas tradições que condenavam na Antiguidade a feitura e o culto de imagens, os padres da igreja e seus sucessores não hesitaram em valorizar as imagens como um indispensável discurso e recurso retórico. Conforme aponta Alain Besançon em sua história da iconoclastia, ocorreu uma impregnação do culto imagético aos imperadores do final da Antiguidade que tingiu o culto das imagens religiosas cristãs. Segundo ele, "no final do século VI, os imperadores não apenas encorajam uma veneração das imagens religiosas análoga àquela das imagens imperiais, como permitem ao Cristo e à Virgem instalar-se no espaço antes ocupado por suas imagens, e, desse modo, receber o culto francamente pagão que suas imagens haviam sempre recebido." (1997: 186)1 É digno de nota que o papa João Paulo II na sua carta apostólica "Duodecimum saeculum", se volta, ao comemorar o XII centenário do II Concílio de Nicéia (de 787), justamente para a importância das imagens na doutrinação cristã. O papa recordou que neste concílio anulou-se os decretos da assembleia iconoclasta de Hiéria (754) e se reestabeleceu o "culto das imagens" (2020: 14). Ele não via o perigo da veneração de imagens transbordar em "práticas idolátricas do paganismo" pois, "segundo a fórmula de São Basílio, recordada pelo concílio Niceno II, [...] 'a honra prestada ao ícone é dirigida ao protótipo.'” E o papa continua seu raciocínio: "No Ocidente, o Papa são Gregório Magno tinha insistido no caráter didático das pinturas nas igrejas, úteis para que os analfabetos, 'ao contemplá-las, possam ler, pelo menos nas paredes, aquilo que não são capazes de ler nos livros', e acentuava que esta contemplação devia levar à adoração da 'única e onipotente Trindade Santíssima.'" (2020: 17) É interessante que essa doutrina funde um platonismo iconófilo (as imagens, apesar de serem cópias, remetem ao protótipo sem imagem) e uma prática de catequese pelas imagens. São João Damasceno, também mencionado por

1 Walter Benjamin, em sua viagem a Moscou em 1927, acompanhou uma outra substituição: desta feita a dos ícones ortodoxos por figuras de Lênin. A idolatria secularizada pelo comunismo não abriu mão da longa tradição da retórica das imagens. (Benjamin 1989: 81) 
João Paulo II nesta carta, em sua apologia Contra aqueles que condenam as imagens sagradas (primeira reação à onda iconoclasta desencadeada pelos imperadores isáuricos Leão III e Constantino $V$ e que influenciou os debates no segundo concílio de Nicéia) também tinha plena consciência da força retórica das imagens. Damasceno segue essa interpretação iconófila da doutrina platônica das imagens: "Nós O proclamamos também pelos nossos sentidos por todos os lados e santificamos o sentido mais nobre, que é o da visão. A imagem é um memorial, exatamente como as palavras são para um ouvido que escuta. O que o livro é para os letrados, a imagem é para os analfabetos. A imagem fala à vista assim como as palavras ao ouvido: ela nos traz entendimento." (2020: 60) Para Damasceno, assim como posteriormente se defenderão da iconoclastia outros doutrinadores iconofílicos, o milagre da encarnação justifica a veneração das imagens:

A natureza humana não foi perdida na divindade, mas como o Verbo feito carne permaneceu Verbo, assim também a carne tornou-se Verbo permanecendo carne, vindo a ser, antes, uma com o Verbo pela união hipostática. Portanto, atrevo-me a traçar uma imagem do Deus invisível, não como invisível, mas como feito visível por nossa causa, através da carne e do sangue. Não traço uma imagem da Divindade imortal, eu retrato a carne visível de Deus. Pois se é impossível representar um espírito qualquer, quanto mais Deus que lhe dá o alento! (2020: 52)

Na hermenêutica teológica de Damasceno, devemos aprender a ler a Bíblia buscando também o Espírito, sob a sua Letra. Assim, devemos compreender as inúmeras passagens iconoclastas do texto bíblico no sentido figurado: "Vede que o único objetivo é não reverenciar a criatura mais do que o Criador, nem dar culto de latria a não ser somente a Ele." (202: 53) Citando a passagem acima transcrita do Deuteronômio 12, 3, Damasceno esclarece: "Vede que Ele proíbe fazer imagens devido à idolatria, e que é impossível fazer uma imagem do deus ilimitado, imensurável e invisível. [...] Essas prescrições foram dadas aos judeus por causa de sua propensão à idolatria." (2020: 54) Diante da frase de Êxodo 33.20, "Não poderás ver sua face", o santo comenta:

Que sabedoria a do legislador! Como retratar o invisível? Como imaginar o inconcebível? Como dar expressão ao ilimitado, ao incomensurável, ao invisível? Como dar forma à imensidão? Como pintar a imortalidade? Como limitar o mistério? É claro que, quando contemplais o Incorpóreo, tornando-se homem por vossa causa, sereis capazes de vesti-lo, de forma humana. Quando o Invisível se torna visível à carne, pode-se, então, desenhar uma imagem de sua forma." (2020: 54) 
A felix culpa, que está na origem do envio do filho em forma humana para "nos salvar", justifica a profusão de imagens cristãs e diferencia o mundo católico do judaico. Passou-se da acústica para a visualidade do exemplo dos testemunhos dos mártires cujos martírios mimetizam Cristo. (Besançon 1997: 185) A união hipostática da carne com a natureza divina traduz imageticamente a percepção divina. O culto de latria, no entanto, é exclusivo do Senhor, mas a reverência, proskinese, pode ser estendida às imagens. (Besançon 1997: 208) 2 "Não adoro a matéria, adoro o Deus da matéria." (Damasceno 2020: 59) Elas são as "imagens para a lembrança" que devem levar as pessoas a "evitar o mal e imitar o bem". (2020: 576) Existe um princípio de contágio mimético bem claro aqui nessa doutrina. Se Aristóteles reconhecia que temos prazer com a imitação, e que a tragédia educa nossos afetos, os padres da igreja desdobram essa concepção na educação da doutrina.

Essa doutrina, essencial para a catequese, pode ser vista em suas consequências daninhas na nota preliminar do texto de São Damasceno publicado recentemente em tradução no Brasil, em 2020. Nessa nota a autora, Viviane Cristina Princival, critica o Bispo Don Erwin Kreuter, conhecido defensor da causa indígena na região do Xingu, em Altamira, porque, ela não admite que este bispo se gabe de nunca ter batizado um indígena. Além disso a autora da nota condena tanto a teologia da libertação como o fato de que durante o Sínodo da Amazônia de 2019 se tenha apresentado uma imagem simbólica de Pachamama. Para a autora "Com a Pachamama no Sínodo compreendemos que não se pretende que a Sã Doutrina e os dogmas da fé católica sejam levados às comunidades ribeirinhas, mas sim a legitimação de uma mistura inconcebível de símbolos pagãos que atentam contra os pilares de nossa Igreja, sobretudo contra a Tradição e o seu zelo pelo Sagrado, para ensina-Lo a todas as comunidades e povos." (Damasceno 2020: 45) Ou seja, ao fazer as palavras de São Damasceno, do início do século VIII, serem precedidas por essa investida contra a teologia da libertação e contra a visão de mundo ameríndia e seus símbolos, vemos como a querela iconoclasta

2 Nas palavras de João Paulo II: "O Concílio Niceno II, portanto, reafirmou solenemente a distinção tradicional entre 'a verdadeira adoração (latria)' que, 'segundo a nossa fé, é devida somente à natureza divina' e 'a prosternação de honra' (timetiké proskynesis), que é prestada aos ícones, porque 'aquele que se prostra diante do ícone, prostra-se diante da pessoa (a hipóstase) daquele que na figuração é representado." (2020: 19) 
sempre esteve e ainda está no fronte político de luta. Toda política, afinal, é política de imagens. Não estamos tão distantes assim do século VIII.

\section{Moisés e Aarão e a barbárie nazista: o "triunfo da espiritualidade"}

É digno de nota que essa história das imagens, de sua crítica e de sua valorização, tenha sido reativada no século $X X$ - de modo bastante distinto - em meio à ascensão do nazismo. Entre 1927 e 1933 Arnold Schönberg compôs sua ópera "Moses und Aron" ("Moisés e Aarão"). Ela retoma o momento imediatamente posterior à aliança feita por Moisés no monte Sinai, que incluía o pacto de não cultuar imagens. Aarão fez fabricar um bezerro de ouro, para fúria de Moisés que quebrou as tábuas da lei divinas diante desse espetáculo. Na ópera de Schönberg, a primeira frase é de Moisés após receber as leis. Nela afirma-se a unidade e invisibilidade de deus: "Einziger, ewiger, allgegenwärtiger, unsichtbarer und unvorstellbarer Gott...!" ("O único Deus eterno, onipresente, invisível e inimaginável...!") E o Aarão schönbergeano lança a questão: "Você pode amar o que não pode imaginar?" Já o coro, representando o povo idólatra, exige imagens para cultuar: "Mostre-o [Deus] para nós! É assim que queremos nos ajoelhar, é assim que queremos arrastar gado, ouro, grãos e vinho! Seu Deus deve ter tudo se nós somos o seu povo, se ele é nosso Deus, se ele nos protege! Mas onde ele está? Mostre-o para nós!" Em meio ao culto fanático de líderes e do simbolismo nazista que invadia as ruas na Alemanha, Schönberg retomava às vésperas da ascensão de Hitler a cena bíblica do confronto entre $o$ iconoclasta Moisés e o iconófilo irmão Aarão. ${ }^{3}$

Pouco tempo depois da composição dessa ópera de Schönberg, entre 1934 e 1938, partindo em exílio de Viena para Londres, outro judeu, Sigmund Freud, também retornara sua atenção à figura de Moisés para refletir sobre a situação terrível dos judeus europeus de então. Um dos subitens de seu ensaio em três partes $O$ homem Moisés e a religião monoteísta, composto nesse período, intitula-se: "O progresso na espiritualidade". Nesse item, o pai da psicanálise se debruça sobre a complexa relação do povo judeu com a sua

3 Recordo que em 6 de dezembro de 2016, o artista israelense Itay Zalait, erigiu durante a noite, em plena praça Rabin, em Tel Aviv, uma estátua dourada do então primeiro ministro Benjamin Netanyahu. A alusão a esse culto a deuses de araque da cena bíblica era evidente. A ação foi batizada de "King Bibi". Poucas horas depois de levantada, a estátua foi retirada, por falta de permissão da parte do município. Nessa ação Zalait usou a narrativa bíblica para simbolicamente destronar o mandatário autoritário e testar os limites da liberdade de expressão no país. 
"eleição" por parte de Deus. Segundo Freud, se outros povos abandonavam ou castigavam seus deuses se não percebiam que estes lhes traziam felicidade, no caso dos judeus ocorria o contrário: quanto mais sofriam mais se submetiam ao seu deus. Isso teria a ver com a índole do monoteísmo judaico que, Freud explica, abdica de provas visuais dessa devoção divina pelo seu povo. Freud deriva esse condão exatamente da lei mosaica que condena as imagens de deus (e que fora também exaltada na ópera de Schönberg):

Entre as prescrições da religião de Moisés se encontra uma que é mais importante do que de início se percebe. É a proibição de fazer uma imagem de Deus, ou seja, a coação a adorar um deus que não se pode ver. [...] talvez fosse uma nova precaução contra abusos mágicos. Mas aceitar essa proibição implicava um efeito profundo. Pois significava uma preterição da percepção sensorial frente a uma representação que cabe chamar de abstrata, um triunfo da espiritualidade sobre a sensualidade; no sentido rigoroso da expressão, uma renúncia aos impulsos com suas consequências psicologicamente necessárias. (Freud 2014: 156)

Freud nota que os infortúnios políticos aprofundaram essa tendência para a espiritualidade. Logo após a destruição do templo de Jerusalém por Tito foi aberta a primeira escola da Torá. "Desde então, foram a Sagrada Escritura e o empenho espiritual por ela que mantiveram coeso o povo disperso." (2014: 158) Uma comunidade sem Estado e imperador mantem-se únida espiritualmente: fica sem imagens (do poder) para cultuar. (O que mudou bastante com a criação do estado judaico.) Freud estabelece uma ponte ligando a proibição mosaica à renúncia pulsional e à sobrevivência de um povo. Ele mesmo, em meio ao turbilhão dos anos 1930, voltou-se para escrever essa história de renúncia sensual e dedicação espiritual. Quando a política e a cultura haviam sido sequestradas pelo culto à figura do Führer, Freud se dedica à história dessa via espiritual anti cultual.

\section{Destruir as falsas imagens da história}

Quando Freud estava completando seu ensaio sobre Moisés, Walter Benjamin, também exilado, mas em Paris, formulou a sua última produção espiritual: as suas conhecidas teses "Sobre o conceito de história". (2020) Um dado pouco destacado nessas teses e nos manuscritos em torno dela é a reiterada aparição do gesto de "explodir". 
mogêneo e vazio, mas por aquele que vem preenchido pelo tempo-agora [Jetztzeit]. Assim, para Robespierre, a Roma antiga era um passado carregado de tempo-agora, que ele fez explodir [heraussprengt] do continuum da história. A Revolução Francesa compreendia-se como uma Roma ressurgida. Ela citava a Roma antiga exatamente como a moda cita um traje do passado. (2020: 50-51)

Esse modelo de citação temporal está na base do movimento histórico-temporal revolucionário que ele define nessa mesma tese como "o salto de tigre em direção ao passado." A revolução é a explosão da temporalidade linear, com sua lógica cronológica que justifica e replica a dominação. $\mathrm{Na}$ tese XV lemos: "A consciência de fazer explodir o continuum da história é própria das classes revolucionárias no momento de sua ação. A grande Revolução introduziu um novo calendário. O dia que dá início a um calendário funciona como uma câmera rápida da história." (2020: 125) A história aos pedaços, explodida, iconoclasta com relação aos ditos grandes vultos e pseudo heróis, é essa a história dos oprimidos em seu levante revolucionário que interessa a Benjamin. Diferentemente da imagofobia de Schönberg e de Freud, Benjamin pensa em uma revolucionária política das imagens. $\mathrm{Na}$ tese seguinte, seguindo aqui o manuscrito das teses de Hanna Arendt de onde cito, incluindo as rasuras, novamente Benjamin faz uma variação da tese acima citada enfatizando essa necessidade de explosão da matriz burguesa da história como linear e ascendente e que se daria em um tempo vazio e homogêneo:

\begin{abstract}
A história é objeto de uma construção cujo medium é constituído não pelo tempo homogêneo e vazio, mas por aquele que vem preenchido pelo "tempo-agora". Onde o passado está carregado com esse material explosivo, o materialismo histórico |a pesquisa materialista| acende o pavio no continuum homogêneo e vazio da história. Nesse processo se prepara a explosão de uma época para fora desse continuum. (2020: 52-53)
\end{abstract}

Nessa versão da tese (que depois se tornou em outras versões a de número XIV) fica claro o procedimento heurístico-político de Benjamin: deve-se romper, explodir, os falsos contextos, as falsas imagens que projetam um modelo único, linear, de progresso. Antes, deve-se lutar por um tempo fora da noção burguesa de "progresso". Romper com os quadros de memória implica romper com idolatrias que alimentam a reprodução do modelo burguês de dominação. Contra a linearidade épica, Benjamin nos fala de um tempo suspenso, justamente o tempo-agora da explosão, que nos leva a outra constelação política ainda recalcada pelas falsas narrativas. 
O materialista histórico não pode abdicar do conceito de um presente que não seja transição, mas para no tempo e se suspendeu. Pois esse conceito define precisamente o presente em que ele escreve história para sua pessoa. O historicismo apresenta a imagem "eterna" do passado, o materialista histórico tem com ele uma experiência única. Ele deixa aos outros a função de se acabarem no bordel do historicismo com a puta do "era uma vez". Ele se mantém senhor de suas forças: viril o bastante para fazer explodir o continuum da história. (2020: 126-127)

Já nos manuscritos em torno das teses lemos: "o momento épico vai ser inevitavelmente explodido no curso da construção. A liquidação do elemento épico deve ser tomada tal e qual Marx, como autor, a empreendeu no Capital. Ele reconheceu que a história do capital só podia ser feita sobre a ampla estrutura de aço de uma teoria." (2020: 145) Ou seja, ao invés da enganosa narrativa linear e triunfal da história das elites, a partir de Marx, Benjamin vislumbra uma história fundamentada numa "construção", ou seja, com uma forte base teórica que a guia no sentido de produzir a explosão do modelo histórico e historiográfico da burguesia/ do historicismo.

Outro componente fundamental e sempre atual dessa filosofia da história de Benjamin, que a faz urgente, é sua consciência diante das ameaças do perigo que nos espreita no presente. Assim como Schönberg e Freud, também Benjamin escreve a partir da realidade do fascismo e de sua ameaça genocida. Dentre os fragmentos em torno da tese ele escreveu: "É necessária uma teoria da história, a partir da qual se possa encarar o fascismo." (2020: 176) A destruição/explosão é uma ação antifascista. Daí a sua filosofia da história se voltar para o passado (para os mortos e não para um eventual futuro triunfal, como faz a burguesia e a socialdemocracia na sua época) e ao mesmo tempo para o presente (para os oprimidos pela máquina capitalista em sua face/fase fascista):

\footnotetext{
O elemento destrutivo ou crítico na historiografia entra em vigor a partir da explosão da continuidade histórica. A autêntica historiografia não escolhe seu objeto de modo leviano. Ela não o apanha, ela o explode para fora do transcorrer histórico. Esse elemento destrutivo da historiografia deve ser concebido como uma reação a uma constelação de perigo, que ameaça tanto o transmitido quanto os destinatários dessa tradição. A historiografia responde à essa constelação de perigo; ela tem que provar nela a sua presença de espírito <<Geistesgegenwart >>. Nessa constelação de perigo a imagem dialética relampeja num clarão. Ela é idêntica ao objeto histórico; ela justifica a explosão do contínuo. (2020: 165)
}

Imagem dialética, Benjamin define em outro fragmento, "pode ser definida 
como a recordação involuntária da humanidade redimida." (2020: 188) A imagem dialética se dá no instante de contração temporal, no encontro revolucionário do passado com o presente, na interrupção do continuum da dominação, no relampejo redentor. Explodir os quadros históricos tradicionais e que alimentam a manutenção da opressão implica desmistificar a ideia de progresso (como o fez de modo único em sua tese sobre o anjo da história) assim como o conceito humanista-iluminista de cultura, associado a uma concepção antropomórfica do devir histórico de cada nação e de sua formação supostamente homogênea e orgânica. Esse modelo burguês de pensar e concretizar a história a partir dos quadros nacionais e de sua formação é um dispositivo memoricida e genocida, que apaga as diferenças para produzir uma falsa unidade homogênea. Daí Benjamin em vários momentos atacar de modo decisivo esse modelo de abordagem histórica:

A representação de uma história universal está vinculada à do progresso e da cultura $<<$ Kultur $>>$. A fim de que todos os instantes da história da humanidade possam ser enfileirados no encadeamento do progresso, devem ser colocados sob o denominador comum da cultura, da ilustração <<Aufklärung $>>$ [...] do espírito objetivo ou como quer que se queira chamar. (2020: 188)

Esse modelo deve ser explodido, para salvar a história dessa falsificação. Entre os textos de "Sobre o conceito de história" encontra-se também um pequeno e precioso fragmento em que Benjamin cita-se a si mesmo:

\footnotetext{
"Organizar o pessimismo significa... descobrir o espaço de imagem <<Bildraum $>>$... no espaço da ação política. Esse espaço de imagem contudo não se deixa medir de forma contemplativa... Esse procurado espaço de imagem... o mundo de atualidade plena e integral." (Surrealismo) (2020: 184)
}

Aqui Benjamin citou palavras de seu ensaio de 1929, "O Surrealismo. O último instantâneo da inteligência europeia", no qual ele também pregou a necessidade de se "Mobilizar para a revolução as forças da embriaguez". (2012a: 33) Tratava-se daquilo que ele denominou, inspirado no surrealista Pierre Naville, de "organização do pessimismo". (2012a: 34) Nada mais atual. A tarefa que ele se colocava era a de alterar radicalmente a relação entre a política e a moral a partir dessa mobilização. Nessa visão, em oposição ao otimismo burguês da social-democracia e ao "arcabouço imagético" dos seus poetas, prega-se um pessimismo de princípio como guia para a mudança. $\mathrm{E}$ sobretudo: trata-se de uma clara consciência de que o único "avanço" alcan- 
çável no atual modelo capitalista é o da técnica que leva à destruição. Para organizar o pessimismo seria necessário "simplesmente extirpar a metáfora moral da esfera da política, e descobrir no espaço da ação política o espaço completo da imagem [den hundertprozentigen Bildraum]." (2012a: 34) Ou seja, tratava-se e trata-se, ontem como hoje, de reconhecer na política voltada para o moralismo, para a "luta contra os corruptos", para a higiene que eliminaria os "esquerdistas", a mais clara expressão do fascismo.

Benjamin formula aqui o embrião de uma técnica do artista (que vale também para o intelectual) que consiste em extrair da ação um novo e poderoso espaço de imagem, Bildraum correspondente a um mundo "em sua atualidade completa e multifacetada" que leva a uma destruição da imagem do indivíduo. Ele denomina esse processo de "destruição dialética". É essa destruição mesma que garante o novo espaço de imagem, Bildraum, que ele descreve de modo mais concreto como um "espaço de corpo", Leibraum, que também tem um sentido coletivo nesse autor: "Também o coletivo é corpóreo". (2012a: $35)^{4}$ Assim, ele reivindica um novo materialismo antropológico, inspirado nos surrealistas. Nesse materialismo é o espaço da imagem que permite uma ação efetiva no presente. Como produzir a destruição dialética das falsas totalidades através de obras que apresentem o presente "em sua atualidade completa e multifacetada"? Como extirpar a metáfora moral da esfera política? Trata-se de uma guerra de imagens que incidem sobre nossos corpos e os dominam. Saber organizar o pessimismo construindo um outro campo imagético como espaço corpóreo é uma das tarefas principais da cultura hoje. A produção cultural se tornou espaço de resistência - e por isso está sendo, como à época de Benjamin, perseguida e tentativamente calada e destruída.

\section{O caráter destrutivo de Benjamin}

Esse projeto de Benjamin também tinha por lema, como lemos em outro fragmento às teses: "Função da utopia política: iluminar o setor digno de ser destruído." (2020: 175) Os sonhos, os desejos e as paixões revolucionárias guiariam as nossas mãos (e cabeças) no trabalho de destruição necessário

4 Em seu A obra de arte na era de sua reprodutibilidade técnica (2013: 33, 62, 63, 83, 85 ) esse projeto fopi formulado no sentido de se construir um novo Spielraum, campo de ação, mas também espaço de jogo, campo de ação política. 
para abrir espaço para a criação de um novo mundo. Esse tipo de ideia já havia sido desenvolvido por Benjamin em 1931 em um texto profundamente ambíguo intitulado "O caráter destrutivo". Considero esse texto ambíguo porque ele toma partido da destruição sem, como nas teses, no ensaio sobre os surrealistas ou no seu ensaio sobre a obra de arte (2013), propor essa filosofia redencionista da história. Mas no contexto desta pequena história da iconoclastia, não podemos deixar de lembrar desse texto, que tem também traços geniais.

Esse escrito de 1931 decreta: "O caráter destrutivo só conhece um lema: criar espaço; só uma atividade: despejar. Sua necessidade de ar fresco e espaço livre é mais forte que qualquer ódio." (Benjamin 2012b: 242) "Criar espaço", "Platz schaffen", também é parte da doutrina nazista de se expandir o "Lebensraum", "espaço vital"... É essa ambiguidade, entre um projeto crítico de destruição positiva, e o projeto necropolítico de destruição negativa, que tenciona todo esse texto benjaminiano. Leiamos mais:

O caráter destrutivo é jovial e alegre. Pois destruir rejuvenesce, já que remove os vestígios de nossa própria idade; traz alegria, já que, para o destruidor, toda remoção significa uma perfeita subtração ou mesmo uma radiciação de seu próprio estado. $O$ que nos conduz a essa imagem apolínea do destruidor, mais do que nunca, é o reconhecimento de como o mundo se simplifica enormemente quando posto à prova quanto ao merecimento de sua destruição. Este é um grande vínculo que enlaça em concordância tudo o que existe. Esta é uma visão que proporciona ao caráter destrutivo um espetáculo da mais profunda harmonia. (2012b: 242)

Sem dúvida essa simplificação maniqueísta do mundo do destruidor é também aquela que vemos nas massas manipuladas por déspotas de ontem e de hoje e sobre as quais Benjamin escreveu criticamente em mais de uma ocasião. (2013: 141-142) O caráter destruidor é mais iconoclasta que iconólatra: o vazio como meta também o impele à destruição:

O caráter destrutivo não idealiza imagens. Ele tem poucas necessidades, e esta seria a mais insignificante: saber o que vai substituir a coisa destruída. Antes de qualquer coisa, no mínimo por um instante: o espaço vazio, o lugar onde se achava o objeto, onde vivia a vítima. Com certeza se encontrará alguém que precise dele sem ocupá-lo. (2012b: 242)

Daí também o caráter destrutivo aniquilar, não penas destruir pois: "O caráter destrutivo elimina até mesmo os vestígios da destruição." (2012b: 
243) Como o déspota genocida também não quer deixar traços de seus crimes... Além disso, como não se esforça por criar imagens, tampouco ele é criativo, antes ele é a encarnação do político: "O caráter destrutivo faz seu trabalho, evitando apenas o criativo. Assim como o criador busca para si a solidão, o destruidor deve estar permanentemente rodeado de pessoas, de testemunhas de sua eficiência." (2012b: 242) Conhecemos bem demais esses políticos eficientes... podem matar mais de meio milhão de pessoas e continuar manipulando seus seguidores.

Mas se essa leitura fascista (ou como alegoria da própria Modernidade) é possível, também pode-se fazer uma leitura progressista revolucionária desse fascinante texto. $O$ caráter destrutivo, como o autor como produtor benjaminiano, sabe aparelhar a sociedade para o novo: "O caráter destrutivo está no front dos tradicionalistas. Alguns transmitem as coisas, tornando-as intocáveis e conservando-as; outros transmitem as situações, tornando-as manejáveis e liquidando-as. Estes são os chamados destrutivos." (2012b: 243) Por fim, esse caráter destruidor, como o historiador materialista, explode os muros que contém as falsas narrativas, depõe os falsos deuses, abre caminhos para os sonhos recalcados, é o mestre das encruzilhadas e não das largas avenidas haussmannianas, escoamento do "progresso" e das tropas de polícia:

O caráter destrutivo não vê nada de duradouro. Mas eis precisamente por que vê caminhos por toda parte. Onde outros esbarram em muros ou montanhas, também aí ele vê um caminho. Já que o vê por toda parte, tem de desobstruí-lo também por toda parte. Nem sempre com violência brutal, às vezes com a mais refinada. Já que vê caminhos por toda parte, está sempre na encruzilhada. Nenhum momento é capaz de saber o que o próximo traz. O que existe ele converte em ruínas, não por causa das ruínas, mas por causa do caminho que passa através delas. (2012b: 243)

\section{O Pós Segunda Guerra: a impossibilidade das imagens e o sublime}

Sempre que Adorno reformulou a frase de seu ensaio "Crítica cultural e sociedade" que indica uma mudez poética pós Auschwitz ele fez questão de manter-se na aporia. O que ele varia é a reflexão sobre a possibilidade da existência da arte após aquela catástrofe, mas não seu estatuto contraditó- 
rio, auto-destrutivo mesmo. ${ }^{5}$ Daí esta frase de Adorno, apesar do equívoco nela contida, ser um dos momentos de maior verdade na reflexão estética do século XX. Na sua Teoria Estética, por exemplo, ele deixa clara a ressalva de que após Auschwitz a arte não pode mais pretender ser inocentemente alegre. Para ele "o conceito de deleite artístico enquanto constitutivo deve ser eliminado." (Adorno 1982 27; Adorno 1973 30). Como ele escreveu em 1962 em seu trabalho "Engagement", também referindo-se ao seu texto de 1949: "O excesso de sofrimento real não permite esquecimento; a palavra teológica de Pascal 'on ne doit plus dormir' deve-se secularizar. [...] aquele sofrimento [...] requer também a permanência da arte que proíbe." (Adorno 1973a 64) "On ne doit plus dormir": o imperativo é aqui, como no Passagenwerk de Benjamin, o do despertar, e sobretudo o despertar para a morte do outro. Mas Adorno imediatamente dispara o gatilho de sua dialética negativa e problematiza (sem interditar) a arte extraída do sofrimento:

\begin{abstract}
A chamada configuração artística da crua dor corporal dos castigados com coronhas contém, mesmo que de muito longe, o potencial de espremendo-se escorrer prazer. [...] Pelo princípio da estilização estética e até pela prece solene do coro [nas tragédias], o destino imponderável se apresenta como se tivesse tido algum sentido algum dia; é transfigurado e tira-se um pouco de seu horror. Basta isso para fazer-se injustiça às vítimas, quando, entretanto, perante a justiça nenhuma arte que evitasse o caminho delas resistiria. (Adorno 1973a 64s.)
\end{abstract}

A arte mesmo de um radicalismo estético como o de Schönberg no seu Überlebende von Warschau (Sobrevivente de Varsóvia), ou da literatura de um Kafka e de Beckett, não deixa de ser também traição na mesma medida em que é consolo. Mesmo assim, pondera Adorno, "não há quase outro lugar [senão na arte] em que o sofrimento encontre a sua própria voz" (Adorno 1973a 64; Adorno 1981 423). Ou ainda, como lemos em "A arte e as artes" ("Die Kunst und die Künste", 1966, publicado no volume

5 O poeta Hans Magnus Enzensberger em um artigo de 1959 publicado na revista Merkur refutou as palavras de Adorno de modo veemente: " "O filósofo Adorno proferiu um teorema que pertence às mais duras sentenças que poderiam ser decretadas sobre nossa época: após Auschwitz não seria mais possível escrever um poema. Se quisermos continuar a viver este teorema deve ser refutado. Poucos podem fazê-lo. Dentre eles encontramos Nelly Sachs. É inerente à sua língua algo de salvífico. Na medida em que fala ela devolve, frase a frase, a nós mesmos aquilo que estamos ameaçados de perder: língua." (Apud Bonheim 2002 7) 
Ohne Leitbild de 1967):

Enquanto a situação não admite mais a arte - neste sentido que ia o teorema sobre a impossibilidade de poemas após Auschwitz -, ela precisa sim dela. Pois a realidade sem-imagem [die bilderlose Realität] tornou-se a completa contraparte da situação sem-imagem, na qual a arte desapareceria, pois a utopia, que se inscreve em toda obra de arte, teria se realizado. (Adorno 1967 192)

O buraco negro do inumano, a mudez da violência crua encontra-se aqui nesta passagem com a luminosidade plena e também não representável, da realização da utopia. Se a arte é inscrição do sofrimento, no mundo utópico realizado não haveria a necessidade da arte.

Esse ser sem imagem da realidade, die bilderlose Realität, - que reaparece como metáfora negativa central no filme de Rithy Panh sobre sua experiência de sobrevivente do Khmer vermelho, L'image manquante ("A imagem que falta", 2013) - remete-nos ao conceito de sublime, que havia sido revalorizado na época da fundação moderna da estética, por autores como Edmund Burke, Moses Mendelssohn, G. E. Lessing, Kant e Hegel. Adorno também trata deste elemento sem-imagem na sua Teoria Estética, quando ele detecta uma "invasão do sublime na arte", "Invasion des Erhabenen in die Kunst”, a partir do final do século XVIII. (Adorno 1982 222; Adorno 1973 292) Este sublime, ele aproxima do "desencadeamento do elementar", "die Entfesselung des Elementarischen", sendo que o espírito da arte é descrito por ele como "autoconsciência" de nosso "ser natural". A arte passa a ser comandada a partir de então por uma dialética entre o "espiritual", e o "elementar" (ou "repelente", "nicht wohlgefällig", "desagradável”, "abstoßend": em uma palavra o nosso "ser natureza" sempre recalcado ou o nosso ser "apenas um animal" que Schiller tentara descartar da literatura). Adorno nota que "o que é sensualmente desagradável possui uma afinidade com o espírito”. (Adorno 1973 292) O sublime penetra, para ele, as configurações artísticas, tornando-se "latente", onipresente, nas obras.

Este sublime não é mais o da teoria estética de Kant ou de um Schiller, mas sim a indicação desse inumano, do sem-representação, do sem-imagem. Mas é verdade que já o autor anônimo do primeiro tratado Sobre o sublime havia visto no silêncio uma das mais intensas manifestação do sublime: "O sublime é o reboo da grandeza da alma. Por isso, mesmo sem uma palavra, suscita admiração de per si um mero pensamento, graças à sua grandeza mesma, como o silêncio de Ajax na Evocação dos Mortos [da Odisséia, II, 453], algo grandioso 
e mais sublime do que qualquer palavra." (1988: 78)6 É importante lembrar que a teoria do sublime do chamado Pseudo-Longino é uma teoria retórica, do convencimento pelo uso de imagens arrebatadoras. Assim, ele enfatiza a força persuasiva da emoção desencadeada pelo sublime, como mais forte que os argumentos lógicos. Para ele, "o sublime, surgido no momento certo, tudo dispersa como um raio e manifesta, inteira, de um jato, a força do orador." (1988: 72) Como no relampejar da imagem dialética benjaminiana que vimos acima, a ruptura sublime indica um irromper de uma força antes recalcada.

Jean-François Lyotard, nos anos 1970, vai retomar o conceito de sublime para tratar de obras de artistas como Barnett Newman, com seus traços, zips, funcionando como linhas de força intensas, conectando a terra e o céu, em um instante. $O$ inapresentável, uma estética da ausência seriam a marca das obras do pintor norte-americano. Em outra vertente, na mesma época o cineasta Claude Lanzmann inicia a filmagem de seu documentário "épico", Shoah (1985), que tentava também formular uma nova estética aliada à ética da representação e derivada do excesso de dor e de morte. Também Lanzmann com seu filme quis apresentar, nas palavras que vimos com Adorno, "a realidade sem-imagem [die bilderlose Realität]", em um filme que recusa utilizar imagens de documentário, que ele denominava de "images sans imagination" ("imagens sem imaginação", 2000), e se baseia na voz, na acústica, relembrando o que lemos sobre a mística judaica da voz (por mais que Lanzmann tenha recusado essa ligação).

Essa estética negativa de Lanzmann já havia sido moldada em debates na França em torno da apresentação da Shoah no cinema. Em um artigo do número 120 dos Cahiers du cinema, Jacques Rivette fizera uma crítica arrasadora do filme Kapo, de Gilio Pontecorvo (1960), por sua estetização do horror. $O$ trecho que interessa aqui dessa resenha merece ser citado, pois ele ainda inspira uma contra-estética ética da apresentação da barbárie:

Veja, no entanto, em Kapò, o plano em que Riva se suicida, atirando-se sobre o arame farpado eletrificado: o homem que decide, neste momento, fazer um travelling para a

6 E Benjamin, em seu ensaio sobre o drama barro alemão complementa: "O silêncio trágico, mais ainda que o pathos trágico, tornou-se o lugar de uma experiência do sublime na expressão linguística, uma experiência que vive geralmente de forma mais intensa na escrita dos Antigos do que na que veio depois." (2004: 110) 
frente para reenquadrar o cadáver desde baixo, tomando o cuidado de registrar exatamente a mão levantada em um ângulo de seu enquadramento final, este homem só tem direito ao mais profundo desprezo. ${ }^{7}$

O que é questionado aqui é uma determinada estetização da catástrofe. "Pas de fiction aprés [le film Nuit et Brouillard de] Resnais", afirmou Serge Daney ("Nada de ficção após [o filme Nuit et Brouillard de] Resnais"; 1992: 15), inspirado nesse artigo de Rivette e reciclando o famoso dictum de Adorno.

\section{Você não viu nada em Hiroshima}

Em 1960, mesmo ano de Kapo de Pontecorvo, Marguerite Duras publicou o livro Hiroshima mon amour com o roteiro que servira de base para o filme de Alain Resnais de mesmo nome, lançado no ano anterior. Na "Sinopse" inicial do livro-roteiro lemos que "Estamos no verão de 1957, em agosto, em Hiroshima" e uma francesa que se encontrava na cidade para fazer um filme sobre a paz, retornará no dia seguinte para a França. Na cena inicial do filme, essa francesa anônima (nunca nomeada) está enlaçada com um japonês, em um ato de amor. Vemos apenas fragmentos de seus corpos e escutamos um diálogo inusitado sobre Hiroshima:

Ela diz a ele que ela viu tudo em HIROSHIMA. Vemos o que ela viu. É horrível. No entanto, ele negará e taxará as imagens que ela viu de mentirosas, e repetirá, de modo impessoal, insuportável, que ela não viu nada em HIROSHIMA.

O primeiro tema será alegórico. Trata-se, em suma, de um tema de ópera. Impossível falar de HIROSHIMA. Tudo o que podemos fazer é falar da impossibilidade de se falar de HIROSHIMA. O conhecimento de Hiroshima sendo a priori posto como uma armadilha exemplar do espírito. (1960: 9-10)

A primeira fala do filme é justamente do arquiteto japonês dizendo e repetindo insistentemente: "Tu n'as rien vu à Hiroshima. Rien" ("Você não viu nada em Hiroshima. Nada." 1960: 22). As imagens do museu sobre a bomba atômica em Hiroshima e também de filmes sobre esse evento são passadas

7 Apud Daney 1992: 5. Desenvolvo a análise dessa polêmica desencadeada por essa crítica de Rivette a Kapo em Seligmann-Silva 2003, p. 81-83. 
intercalando essa cena inicial. A francesa afirma: "J'ai tout vu. Tout." ("Eu vi tudo. Tudo"), para novamente ser contradita pela negativa de seu companheiro. "Tu n'as rien vu à Hiroshima. Rien". Hiroshima é invivivel e in-visível. Apenas uma estética que incorpore essa negação pode tentar indicar essa espaço-temporalidade do trauma.

\section{O horror não tem imagem?}

Quarenta anos depois, por ocasião da exposição com curadoria de Clément Chéroux, Mémoires des Camps Photographies des Camps de Concentration et d'Extermination nazis (1933-1999), Georges Didi-Huberman escreveu um texto para o catálogo dessa mesma exposição criticando aqueles que se referiam a essa estética negativa aqui apresentada ao tratar de Auschwitz. Para ele, isso seria uma questão de "preguiça". (2001: 230) Na ocasião, respondendo a esse ataque, o psicanalista Gérard Wajcman retoma a questão da negatividade para diferenciar os debates sobre a ética da representação, na segunda metade do século XX, da tradição da teologia negativa que também vimos acima. É importante retomar o argumento central de Wajcman:

devemos, portanto, ter o cuidado de sublinhar o quanto o debate real nada tem a ver com qualquer Querela das Imagens opondo seus adoradores a seus destruidores, [...] Quer dizer que quando se trata da impotência da imagem para transmitir todo o real, alguns persistem em compreender uma recusa em mostrar e uma condenação indignada de qualquer imagem tida como sacrilégio. [...] o debate sobre a representação da Shoah, aquele que se trava especialmente a partir do filme Shoah de Claude Lanzmann, não tem absolutamente nada a ver com uma Querela das Imagens, nem com qualquer proibição da representação, nem com qualquer prostração diante de qualquer invisível. Confundir impossível e proibido, pensamento e crença, demonstração lógica e mandamento divino é, na melhor das hipóteses, um grande erro que, na pior das hipóteses, condena a nada entender de tudo isso. (Wajcman 2001: 63)

Para Wajcman, trata-se agora de uma outra querela das imagens, a partir de uma crítica da imagem consoladora, cuja defesa ele percebe nos argumentos de Didi-Huberman. Partindo da psicanálise, da teoria do trauma e do real lacaniano, Wajcman nega a possibilidade dessa representação redentora defendida por Didi-Huberman. Ele fala de imagens sempre insuficientes, aquém do real: 
descobre algo, também o cobre; a imagem nos distrai do que nos faz ver. [...] horror e imagem se repelem, é isso. [...] o horror não tem imagem, fica sem duplo, é único. A imagem é um duplo. (2001: 68)

Na sua defesa radical do ser inimaginável do horror, Wajcman desdobra uma estética negativa que, no limite, é avessa à fotografia como arte, o que é inaceitável também. Apesar de sua radicalidade que leva o autor às raias do absurdo, sua proposta de levar em conta os limites da imagem é absolutamente correta. Como na frase de 1949 de Adorno, tem algo de insuportável na radicalidade de Wajcman, mas também algo de verdadeiro. Quando ele afirma que "Voir les images peut être une façon de satisfaire l'envie de ne rien voir, de fermer les yeux" "Ver fotos pode ser uma forma de satisfazer o desejo de não ver nada, de fechar os olhos." 2001: 76), pensamos no tema das imagens cegadas (perfuradas, escondidas, queimadas etc.) e nos gestos de se fechar os olhos que encontramos na arte contemporânea que enfrenta o desafio de apresentar esse real do trauma. $\mathrm{Na}$ arte contemporânea precariza-se as imagens para mostrar essa inimagibilidade do real. (Seligmann-Silva 2014) Ou seja, ao invés de um elogio fácil das imagens e da nossa capacidade de imaginar, Wajcman recoloca a querela das imagens no século XX (e no nosso também) do ponto de vista das aporias que cercam a representação. A questão é como mostrar as imagens sem fazer delas uma proteção ou consolo que alimenta o oblívio.

\section{A virada testemunhal e decolonial da cultura/ do saber}

Paralela a essas discussões desencadeadas pelo terror das guerras e genocídios do século XX, encontra-se um profundo debate, mais amplo e cheio de reverberações, que conecta essas questões em torno da apresentabilidade da violência ao sistema da Modernidade como uma máquina genocida. Refiro-me às lutas pela descolonização e ao pensamento pós e decolonial derivado dessas lutas.

Em 2019 o curador camaronense radicado em Berlim, Bonaventure Soh Bejeng Ndikung propôs pensarmos um conceito de des-outrização como estratégia de crítica e desconstrução das geografias e narrativas que instituem poderes centrais em nossas sociedades. Seu texto para o catálogo da $21^{a}$ Bienal VideoBrasil teve por título "Des-outrização como método" e levou como subtítulo uma frase em ngemba que, traduzindo, significa algo como "mantenha o seu que eu mantenho o meu". Vejamos como esse tex- 
to pode ser lido como uma proposta de revisão dos hábitos coloniais de se pensar a nossa auto-representação, ou seja, como um projeto de explosão de modelos históricos tradicionais. Proponho pensarmos a partir desse texto de Ndikung uma memória que seria uma outra versão da história: uma verdadeira contra-tradução empoderadora da tradição, uma autêntica escrita a contrapelo, no sentido benjaminiano do termo.

É importante destacar que o texto se apresenta como parte de um projeto que nasce em resposta à ascensão de "supremacistas patriarcais brancos da extrema-direita" em eleições nos EUA e "em diversos países europeus" (Ndikung 2019: 65). Podemos sem problemas acrescentar a América Latina nesse contexto. A desoutrização responde, portanto, a um processo político que pode ser acompanhado de modo claro desde os anos 1990, que permitiu o que Ndikung chama de "canibalização da outridade", ou seja, um movimento sobretudo ocidental de incorporação de seus "outros", acompanhado, no entanto, pela criação brutal de novas outrizações, sobretudo voltadas contra o mundo árabe, movimento que ele chama de "regurgitação de outridade" (Ndikung 2019: 61). Nesse processo que se dá a referida ascensão supremacista que acaba por reforçar os mecanismos de outrização. Com Freud, de seu ensaio "Massenpsychologie und Ich-Analyse" ("Psicologia das massas e análise do eu", 1921), ou com o René Girard de La violence et le sacré (1972) poderíamos pensar essa outrização violenta da qual Ndikung nos fala, como a criação de bodes expiatórios, de grupos que são estigmatizados e sacrificados em nome da manutenção da lei e da ordem. Mas ele atualiza essa questão ao mostrar um movimento sutil que ele chama de Soft power, que consiste na representação aparentemente inclusiva dos outrizados, como ocorre em exposições e eventos públicos voltados quer à África, quer ao "mundo árabe".

O "Outro", recorda Ndikung, acompanhando aqui uma série de autores decoloniais, como Stuart Hall, Achille Mbembe e Grada Kilomba, é uma superfície de projeção de medos. "Outrizar" é criar um monstro a partir de si e lança-lo sobre a imagem do "Outro" para conseguir viver melhor consigo mesmo. O "outrizado" vive sob uma opressão econômica que é de certo modo garantida pela opressão simbólica que impede que ele seja um "eu". Assim, Grada Kilomba narra a libertação que significou para ela sair de Portugal e ir para Berlim. Ela fala de uma urgência vital nessa saída: "Não havia nada mais urgente para mim do que sair, para poder aprender uma nova linguagem. Um novo vocabulário, no qual eu pudesse finalmente 
encontrar-me. No qual eu pudesse ser eu" (Kilomba 2019: 11). O outro é ao mesmo tempo rejeitado, visto como o mal, e também desejado sexualmente: nos dois momentos da projeção ele é objetificado, destituído de self pelo "outrizador"/ "otherer".

O método da "desoutrização", consiste, então, em procedimentos voltados para, antes de mais nada, inscrever de modo claro tornando consciente ao "otherer" e sobretudo ao "outrizado" esse mecanismo colonizador. Trata-se de interromper, explodir e barrar a continuidade da longa narrativa colonial. Essa produção de consciência deve, por sua vez, estar na base de uma resistência às reinvestidas neocoloniais. Cabe pensar em modelos de viver juntos para além da lógica da outrização e do ser outrizado. Ndikung está consciente, como também tem enfatizado Achille Mbembe, quanto à íntima relação entre a racialização, a outrização, o colonialismo e sua volta neocolonial, com o modelo capitalista. A comoditização e a lógica do lucro transformam pessoas e a natureza em engrenagens do sistema. A proposta de Ndikung é a de "demolição de cartografias de poder" (destruir as falsas narrativas coloniais) e de "recalibragem das relações humanas e não humanas, espaciais e sociais" baseada em uma "interdependência de todos os seres animados e inanimados que coabitam este mundo" (Ndikung 2019: 64).

O logos ocidental, seu logocentrismo que anula outras manifestações que diferem da tradição eurocêntrica, é outrofóbico e, no limite, outricida. O "outro" é considerado como estando fora do lugar da produção do saber, ele se encontra apenas no lugar específico que é sempre antípoda do local do saber, trata-se de um local atópico, sem lugar. Kilomba escreve: "Corpos brancos, ao contrário, são construídos como próprios, são corpos que estão 'no lugar', 'em casa', corpos que sempre pertencem. Eles pertencem a todos os lugares: na Europa, na África, no norte, no sul, leste, oeste, no centro, bem como na periferia" (Kilomba 2019: 56). As intelectuais negras estariam fadadas a habitar a periferia, as margens. Daí os estudos decoloniais contemporâneos não deverem mais reproduzir inocentemente essas dicotomias centro/periferia, capital/margens etc. O corpo que é condenado pelo discurso colonial a viver sem casa, condenado ao Unbehagen (mal-estar) e ao Unheimlich (ominoso), deve, antes, ser reconhecido como um ator igualmente digno na construção dos saberes, das casas e dos locais. O pensamento decolonial explode assim com essas bipolaridades estanques, assim como prega uma visão aberta da identidade como processo, como devir e deriva, em oposição ao poder colonial enquanto máquina de estampagem e esteriotipia de identidades estanques distribuídas hierarquicamente entre 
"nós" e os "outros". Fanon, Spivak, Hall, Mbembe, A. Nascimento, Kilomba, Ndikung e tantos outros pensadores pós-coloniais partem de suas experiências, de seus corpos e de suas subjetividades, para revelar que todo saber é estruturado a partir de personagens que vivem em sociedade, atuando nela e sofrendo suas coações. A conquista do Leibraum de que Benjamin nos falava revela-se aqui como uma conquista de corpos que sofrem por essa deslocalização esquizofrênica que a sociedade colonial thes impõe. Toda a teoria e produção artístico literária desse universo associado ao projeto de des-outrização pratica constantemente uma repaginação da história. Explode a história colonial para construir essa história a contrapelo a partir da memória do sofrimento e da resistência que em boa parte está inscrita nos corpos.

\section{A arte de desoutrizar: Jaime Lauriano}

A obra de Jaime Lauriano Quem não reagiu está vivo (2015) é composta por

Figura 1 Jaime Lauriano. Quem não reagiu está vivo, 2015 Impressão jato de tinta sobre papel alta alvura, dimensões variáveis (35 x $48 \mathrm{~cm}$ cada).




uma série de dez pranchas com folhas enquadradas sob material transparente, cada qual com uma imagem na parte superior, um título no meio e um texto em português e inglês na metade de baixo. Essa forma lembra, não por acaso, a forma barroca do emblema, que era caracterizada pelo jogo entre um título, um texto em forma de poema ou de prosa e uma imagem. $O$ título portava a "moral" do emblema. Aqui nessa obra de Lauriano, os títulos assumem mensagens que visam rever a história do Brasil, orientando-a agora do ponto de vista dos vencidos e espezinhados. Ele concretiza a necessidade de se "escovar a história a contrapelo" (2020: 74), na expressão de Walter Benjamin, contra-arquivando a história. Como Benjamin nota na mesma tese "Sobre o conceito da história", o historiador crítico, o materialista histórico, deve recuar (distanciar-se) criticamente da noção de história tradicional, poderíamos dizer com Nietzsche, monumentalista, que vê na história um cortejo de vencedores e se identifica com ele.

Assim, acompanhamos nas pranchas de Lauriano uma reescritura de uma história que parecia familiar e conhecida, mas que é transformada e revelada em seu fundo de violência recalcada. A primeira prancha recorda a resistência da população africana escravizada no Brasil que construiu o Quilombo dos Palmares. A ilustração, imagem muito reproduzida de Manuel Vítor de 1955, Guerra dos Palmares, retrata a repressão ao quilombo, e o texto enfatiza que esse massacre significou a perpetuação "do direito do homem sobre o homem". A segunda prancha reproduz o conhecido mapa "Terra Brasilis" (1519) cujas imagens comemoram a conquista lusitana, no estilo da empatia com os vencedores. No caso, o mote/título da prancha ("exploração escrava da mão de obra dos povos nativos") e o texto descontroem a imagem do mapa (e uma determinada imagem triunfalista da história). Se a primeira prancha leva a uma empatia com as populações africanas escravizadas e massacradas, nessa prancha o olhar se volta para o sofrimento das populações autóctones. O texto afirma:

\footnotetext{
"O famoso mapa Terra Brasilis - encomendado por Dom Manuel I, e realizado pelos cartógrafos Lopo Homem, Pedro Reinel e Jorge Reinel e ilustrado por António de Holanda - glorifica a Invasão Portuguesa ao 'novo mundo'. Neste exemplar podemos notar como os autores descrevem, e ilustram, o novo continente exaltando a exploração do solo 'brasileiro', a partir da colonização e escravização dos corpos de dezenas de povos indígenas."
}

A terceira prancha enfoca o "extermínio e dissolução de comunidades auto organizadas". No caso, a foto é dos seguidores de Antônio Conselheiro em 
Belo Monte (Canudos). O texto enfatiza que essa população que resistia à "lógica latifundiária que estruturava o solo e a sociedade brasileira" foi massacrada, com um saldo de mais de 25 mil mortos. A quarta prancha também se volta para o conflito no campo, mas enfatiza a "concessão da exploração territorial para empresas estrangeiras". O século XX dá continuidade ao tipo de exploração já apresentada no mapa Terra Brasilis. A quinta prancha estampa o retrato de uma placa erigida em 9 de outubro de 1970, em Altamira, ou seja, em plena Amazônia e na ditadura civil-militar, que serviu de marco para o início da construção da via Transamazônica. O mote enfatiza a "devastação de florestas e extermínio de povos indígenas" e a explicação conecta as "obras faraônicas" da época da ditadura ao desejo de eternização dos presidentes militares, que acarretou na morte de "milhares de povos indígenas". A sexta prancha retoma o tema atual da "repressão policial como tática de genocídio" que na explicação é exemplificada pela Chacina da Candelária, de 1993 no Rio de Janeiro: "o episódio revelou a política, genocida, de higiene social". A prancha seguinte, desdobrando também ideias das pranchas três e seis, foca o "massacre como tática de dispersão de manifestações sociais". O texto recorda outro massacre de resistentes, no caso, os camponeses de Eldorado dos Carajás, assassinados barbaramente pela polícia militar do Estado do Pará em 1996. A oitava prancha é dedicada ao lema "devastação de comunidades para assegurar o progresso da nação". Ela se volta para a construção de uma das mega-hidrelétricas do Norte do país, que gera destruição socioambiental, destrói comunidades locais, tudo isso sob a batuta de um conglomerado violento composto pelo Estado brasileiro e seus aliados empresariais nacionais e internacionais. A nona prancha novamente destaca a resistência contra a aliança do capital com o Estado. $O$ mote é uma citação das palavras do governador do Estado de São Paulo da época do massacre da comunidade de Pinheirinho, no Estado de São Paulo, durante mais um ato bárbaro de reintegração de posse: "quem não reagiu está vivo". Lema cínico de um governo que de modo escancarado assume a sua política de extermínio dos que resistem às imposições do Estado-capital. A política de moradia se revela aqui também como higiene social. A última prancha destaca: "segregação e racismo institucional transfigurados de medidas de segurança social”, ou seja, ela quer desvelar a hipócrita política racista da polícia, no caso, do Rio de Janeiro. As fotos dos emblemas empregadas por Lauriano destacam as imagens dos resistentes: a população de Canudos, o enterro após a Chacina da Candelária, os membros do MST de Eldorado dos Carajás, a comunidade indígena, vítima das barragens das hidroelétricas, a população armada com paus de Pinheirinho "pronta" para enfrentar o batalhão da PM paulista. Com esse foco nas lutas de resistência 


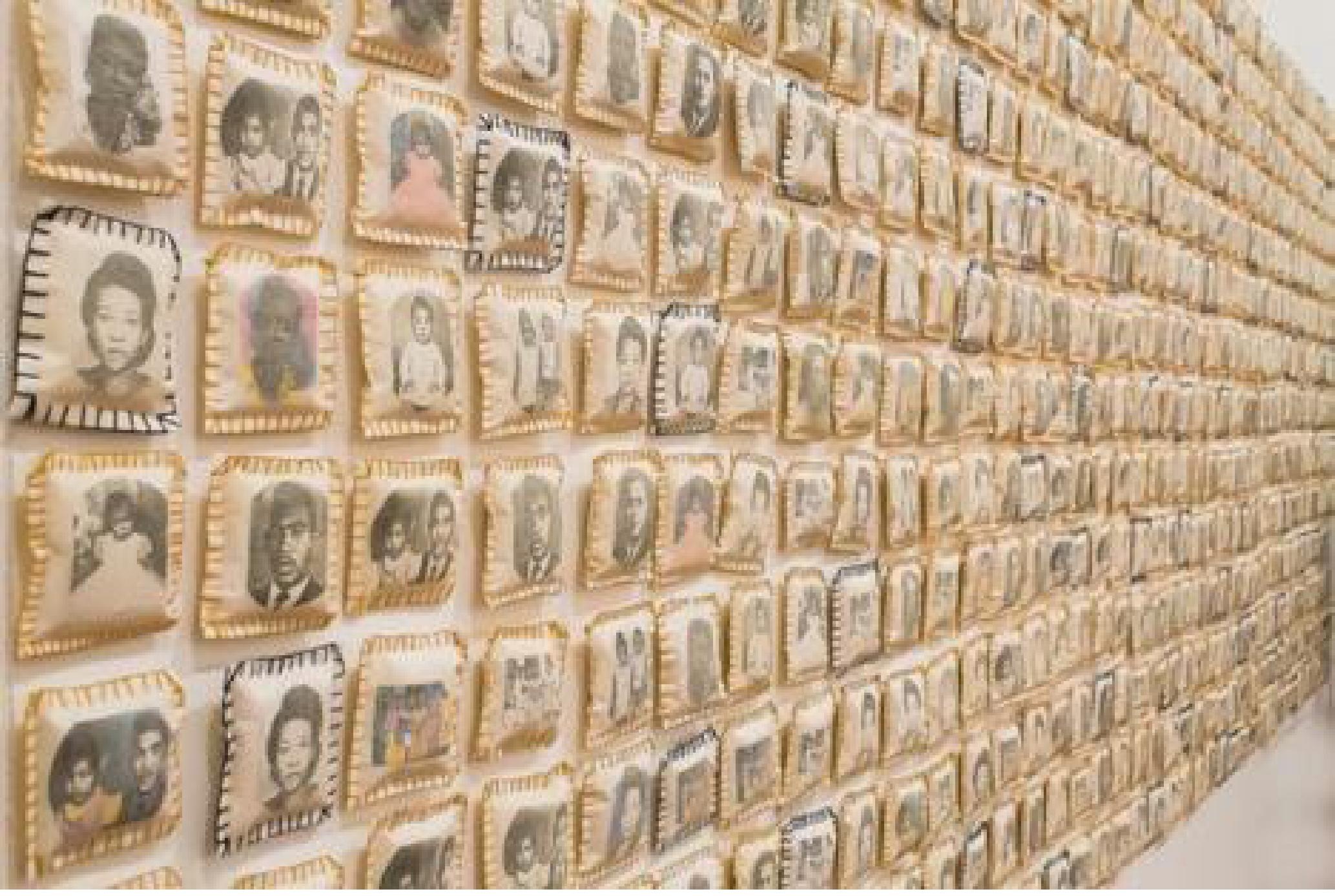

Figura 2 Rosana Paulino. Parede da memória, 1994. Mídia múltipla, 8 × 8 × 3 cada. Fotografia: divulgação da artista

\section{Rosana Paulino: anarquivar o dispositivo colonial}

Proponho olharmos as obras da artista Rosana Paulino como a arte de produzir a ruptura da cumplicidade entre o dispositivo estético e o colonial. Explico-me. O classicismo, que está na base do nascimento da história da arte, com Winckelmann, e também sustenta a teoria estética da arte de Kant e sucedâneos, impõe-se como uma poderosa máquina ontotipológica (Lacoue-Labarthe \& Nancy, 2002). Esse modelo clássico gera o "próprio" eliminando o "outro" que é produzido nesse mesmo gesto de produção/ aniquilação. Estamos diante de um dispositivo, o dispositivo estético, talvez o mais violento que a modernidade criou, pois é a partir dele que se produz a linha divisória entre os dignos de direitos e de solidariedade e aqueles que são a "carne" que alimenta a máquina colonial (Seligmann-Silva, 2019). O dispositivo estético é um aliado do dispositivo colonial, ambos produzem e aniquilam os seus "outros". 
Podemos dizer que a luta que se dá no campo das artes afrodescendentes no Brasil é a luta pelo reconhecimento do elemento violento, ideológico, de apagamento dos negros e de uma miríade de culturas, no bojo dessa ideologia estética "universal" e universalizante (ou seja, aniquiladora dos "outros", do "diferente"), antes de mais nada branca, eurocêntrica e racista.

Rosana Paulino é reconhecida como uma pioneira na nova arte negra brasileira. Sua obra Parede da memória, de 1994, é uma referência dentro dessa produção. Essa obra é composta por 11 fotografias de sua família que se repetem atingindo diferentes números, chegando a atingir 1500 dessas fotos, que são impressas sobre tecido em tamanho de cerca de $8 \times 8 \times 3$ $\mathrm{cm}$ cada, formando patuás, ou seja, um elemento da religiosidade afro, que tem um valor de amuleto no candomblé. Cada patuá leva cores específicas, associadas a Orixás que irão então proteger aquele que porta o talismã. Lembremos que Abdias Nascimento escreveu sobre o candomblé como "o ventre gerador da arte afro-brasileira". (2016, p. 125) É importante lembrar que a própria Rosana Paulino narra a sua carreira a partir dessa obra emblemática que esteve também presente na sua recente exposição na Pinacoteca de São Paulo de 2018-2019.

Parede da memória, na sua apresentação apenas aparentemente simples, sintetiza na verdade o encontro de vários gestos: o fotográfico, o da costura, o da rememoração tanto da família como de uma origem afro. A obra também alude aos universos da religiosidade, do jogo (jogo de memória) e da montagem, já que se trata de um arranjo que está sempre em movimento, sendo remontado, sem nunca deixar de ser a Parede da Memória. Essa parede com uma série de patuás, não deixa de ser uma versão contemporânea afro dos loci memoriai, os lugares de memória da mnemotécnica. Nessa tradição une-se a memoria rerum, memória das coisas, com a memoria verborum, memória das palavras. Os imagines agentes, ou seja, agentes da memória, são colocados em certos locais para se narrar imageticamente histórias (Yates 1966). Existe um movimento nessa obra de Paulino de apropriação de elementos da memória, de uma memória próxima, familiar, mas também distante, associada a uma ruptura, a uma deriva, de um saber e de um modo de estar no mundo o qual, de certa forma, a artista reconhece como seu. Como nas palavras de Musa Michelle Mattiuzzi, Rosana Paulino parece de fato "habitar as ruínas da colonialidade", ela se apresenta como alguém que sabe "habitar e reviver as ruínas dessa pluralidade afro-atlântica". (Pedrosa ; Carneiro ; Mesquita 2018, 607-609) Sua parede da memória porosa, cheia 
de espaços e em movimento, abre nosso olhar para a uma história que costuma ser sistematicamente apagada, ocultada. Ela atravessa e rompe com o robusto muro do esquecimento erigido pelas narrativas da colonialidade.

A fotografia se tornou uma metáfora fundamental na arte contemporânea e no Brasil tem estado na base da produção de artistas que lidam com a memória e, mais ainda, com o esquecimento. Recordo Hélio Oiticica, com seu Bólide Caixa 18 "Homenagem a Cara e Cavalo, de 1966 ou o seu famoso seja herói, seja marginal de 1968. A fotografia, sobretudo a analógica, tem um momento de "impressão" (vale lembrar que Rosana Paulino é bacharel e especialista em gravura; Lopes 2018: 171). A fotografia reatualiza outras metáforas da memória, como a escritura, metáfora também fundamental na referida tradição da arte da memória com sua ideia de inscrição mnemônica. Afinal, a fotografia é literalmente uma escrita de luz. Mas ela também remete à concepção psicanalítica de nossa memória como composta por camadas, umas mais outras menos conscientes. A inscrição do trauma, como veremos, também já foi comparada a um flash fotográfico. Diferentemente da postura de Wajcman que vimos, a fotografia não é pura presença, ela enquanto retrato tem também um elemento corpóreo e fantasmático: o retrato fotográfico literaliza ambiguamente o aparecer e o desaparecer, a presença e a ausência, o desejo de ver e o evanescer da imagem. Paulino se torna também nessa sua obra/jogo quem dá as cartas na cena da apresentação dos corpos negros. Como Eustáquio Neves e seus retratos, ela afirma-se como agente de suas imagens e não mais como objeto representado e sem fala própria. A obra consegue ser ao mesmo tempo extremamente contemporânea e citar passados mais ou menos próximos. Ela é um buraco no tempo, cria uma metaespacialidade e outros cronotopoi. A fotografia é tratada como fragmento, escombro, sobrevivência de um naufrágio e é em torno de fotografias apropriadas, suas cópias, recortes e inversões, que boa parte da obra de Paulino se constrói. Isso sem, no entanto, romancear alguma origem perdida, ou estabelecer alguma ontologia identitária. Antes, a reprodução técnica das fotografias desconstrói qualquer visada essencialista. Trata-se de abrir espaço para se imaginar origens e narrativas alternativas às construídas pelos discursos coloniais.

Na sua série de 1997 de Bastidores, ela costura os olhos, a garganta, a boca e a fronte de retratos fotográficos de mulheres negras colecionadas por ela nos álbuns de sua família. Como em muitas obras de Rosangela Rennó, essas fotografias são prograticamente precarizadas, para indicar apagamentos, 
perdas, subtrações, mas também para indicar que essas mulheres são ao mesmo tempo indivíduos singulares o mesmo valendo para todas aquelas que se identificam com elas. $O$ ato da artista é sempre duplo: ao costurar a boca e o pescoço ela se assume como agente da fala, descosturando a sua boca e a de quem admira o seu trabalho. Ao costurar os olhos ela se institui como agente na construção das imagens e do imaginário contracolonial, descosturando os seus olhos e os dos que veem sua obra. Ao costurar a fronte ela se assume como agente pensante e não como objeto pensado, dissecado pela ciência e esmagado pelo trabalho servil, descosturando o seu cérebro e do seu espectador. Em uma palavra, ela afirma: sou dona do meu corpo, a mulher negra manda em seu corpo, isso em uma sociedade ainda colonial, falocêntrica, racista que oprime tanto corpos negros como femininos ou que não correspondam ao padrão hetero-cisgênero. Ao denominar sua obra Bastidores ela joga com o significado múltiplo do termo: por um lado, ela explicita os bastidores dessa sociedade com seu gesto de costurar nos rostos desses retratos. Mas bastidor remete aqui também ao suporte da tecelagem que é onde essas fotografias foram impressas. Ao invés de costurar "comportadamente" e fazer as suas tecelagens cumprindo o papel "feminino" que a sociedade impõe às mulheres, Paulino desloca o bastidor, rompe com seu papel de instrumento de controle de gênero e transforma-o em dispositivo de sua arte eminentemente política. Esse gesto, de resto, tem sido recorrente entre mulheres resistentes e revolucionárias da história e da memória na América Latina, como as "Arpilleras" do Chile.

\section{Alfredo Jaar: a tarefa de encarar de frente as imagens do horror}

Por fim recordo dos trabalhos do artista chileno Alfredo Jaar. Eles têm por marca um duplo movimento: colocar o público diante de imagens que normalmente estão ou censuradas ou transformadas em clichês e, por outro lado, denunciar a desaparição das imagens em mundo saturado delas. Sobre a desaparição (ou falta de imagens) vejamos sua obra Untitled (Newsweek), de 1994, ano do genocídio da população tutsi em Ruanda. Essa obra de Jaar é um trabalho quase psicanalítico de inscrição de uma memória recalcada. Jaar monta nessa obra dezessete pranchas compostas pelas dezessete capas da revista Newsweek publicadas durante o período no qual se dava o massacre na África. A obra destacava, como na segunda prancha de Lauriano, o contraste entre a realidade e a sua representação "oficial". A suposta revista de notícias e informação passou cem dias sem noticiar que se dava naquele momento um dos genocídios mais sangrentos do século. Suas 
capas destacavam as fotos de estrelas do futebol e da música, lembravam o dia do desembarque aliado na França em 1944, tematizavam o mercado de ações, especulavam sobre a possibilidade de vida em Marte etc. Abaixo de cada imagem que reproduzia essas dezessete capas, o artista escreveu o que acontecia em Ruanda a cada um daqueles momentos. Novamente a arte trabalha aí como escritura a contrapelo, como revelador de imagens que estão sendo o tempo todo recalcadas, riscadas ou mesmo barradas de serem inscritas. $\mathrm{O}$ artista se volta para o sofrimento que a sociedade recusa a ver - a não ser sob o signo da espetacularização ou da manipulação nacionalista, como no caso dos atentados terroristas e de sua cobertura. Esse tipo de imagem espetacular cega ao invés de abrir nossos olhos para o real. A imagem de artista, pelo contrário, pode servir de ponte e acesso para o "outro" e para o real, explodindo com as imagens encobridoras.

Ernst Simmel, autor de Neuroses de guerra e trauma psíquico, 1918, descreveu o trauma de guerra com uma fórmula que deixa clara a relação entre técnica, trauma, violência e o registro de imagens: "A luz do flash do terror cunha/estampa uma impressão fotograficamente exata". Trata-se de uma imagem-cega, que lembra a ideia de Wajcman que afirma a impossibilidade de imagens do horror. Mas Jaar é o artista que nos ajuda a construir e ver essas imagens. A fotografia é uma filha da modernidade e nasce com a propensão ambígua a registrar a realidade violenta e a reproduzir essa mesma realidade. A reprodução técnica é marca da modernidade capitalista (com suas máquinas e guerras), assim como do dispositivo fotográfico. Repetimos ad nauseam a produção de choques e catástrofes que resultam de um sistema de exploração do trabalho, da natureza e dos conflitos nacionais e coloniais. A psicanálise nasceu, nesse contexto, para descrever essas vivências traumáticas e para imaginar terapias para a nossa vida sob o desabrigo (mal-estar) produzido por esses choques.

Diante dessa realidade pontuada pela violência e esmagamento do indivíduo e das sociedades também os artistas, como escreveu Walter Benjamin, têm que tomar posição. Eles podem tanto permanecer (ou tentar permanecer) em uma campânula fechada e protetora, fingindo que essa realidade traumática não viceja lá fora, construindo belos mundos de sonho e harmonia, como também eles podem enfrentar essa realidade do terror. Eles podem tentar olhar de frente a luz ofuscante do horror e fazer parar o automatismo da repetição. Justamente, ficar de pé, resistir, encarar a luz do flash do terror da realidade e inscrevê-la em dispositivos artísticos, essa é a tarefa que alguns artistas assumiram para si e o chileno Alfredo Jaar ocupa um 


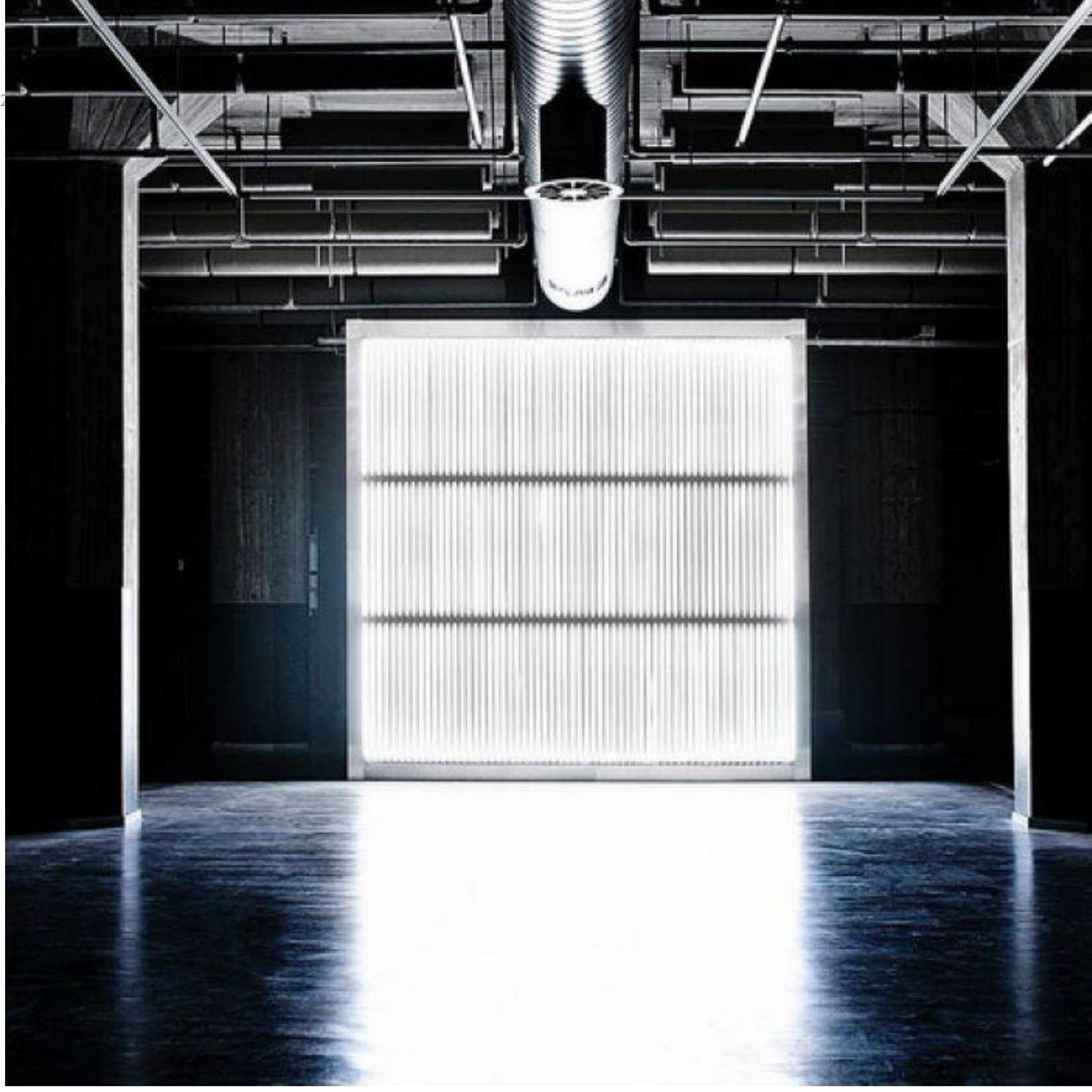

lugar de destaque dentre esses artistas.

Encarar a face da medusa do real (que petrifica e queima) através dos reflexos, das reproduções e dos arranjos curatoriais de Jaar é um modo de se ver, no seu escudo de Perseu, aquilo que normalmente recusamos ver. Uma das obras mais no nosso contexto é "O som do silêncio", de 2006. Em uma caixa-preta superdimensionada, uma autêntica máquina fotográfica na qual adentramos, ele propõe (re)revelar uma imagem que havia sido transformada em clichê. Trata-se da famosa fotografia de Kevin Carter, o fotógrafo sul-africano, que retrata uma criança em um campo no Sudão em 1993. Em duas décadas de guerra naquele país cerca de dois milhões de pessoas foram vitimadas. A criança está caída e atrás dela vemos um enorme abutre. Jaar, em seu dispositivo artístico-mnemônico de ressignificação dessa fotografia, nos faz entrar nesse enorme cubo negro (o reverso do cubo branco modernista que pretendeu romper o compromisso da arte com a história) e assistir a uma projeção de oito minutos, narrando a história de Carter (que depois de receber o prêmio Pulitzer por essa imagem veio 
a se suicidar), com letras brancas sobre um fundo preto. Quando a famosa fotografia é, finalmente, apresentada, fortes flashes disparam sobre o espectador que fica ofuscado/cegado. Cegado de ver, mas também cegado para ver melhor. Trata-se do relampejar de uma imagem dialética. Esse é o paradoxo da poética de Jaar: ao invés de domesticar as imagens de terror que ele coleciona, ele consegue fazer com que elas nos toquem. Jaar ativa o momento real das imagens. Do lado de fora da caixa preta um enorme painel de luzes brancas repete esse mesmo gesto de ofuscamento, como que nos chamando: venham ser ofuscados, para que seus olhos se abram para o real. Para que você (re)nasça para o "outro". Como lemos em outra obra da exposição: "outras pessoas pensam."

Da iconoclastia aos artistas contemporâneos das imagens do trauma e ao projeto de produzir imagens descolonizadoras trilhamos um percurso que permite ainda inúmeros desdobramentos. Repensar o campo cultural a partir da tarefa de romper, explodir, o muro de narrativas coloniais e montar, construir curadorias de imagens que são ressemantizadas no contexto de novas pautas políticas, de novas-antigas epistemologias antes recalcadas é uma tarefa que vai nos ocupar por algumas gerações.

No filme de Alain Resnais a francesa ao final consegue construir uma memória e também a possibilidade de esquecer Hiroshima. Ela atravessou Hiroshima através do encontro com Nevers, a sua cidade na qual ela teve um amor e uma morte durante a guerra. Foi a partir do encontro das mortes, dos traumas, que a memória pôde ser (re)construída. Ver Hiroshima era também conseguir olhar para si mesma, romper com a força da negação. Não há imagens para Hiroshima, mas o encontro das imagens que faltam, da ausência de imagens produziu um filme, produziu uma recordação e um renascer para a vida.

\section{Referências}

ADORNO, Th. "Crítica cultural e sociedade", in: Prismas. S. Paulo: Ática, 2001, p. 7-26.

ADORNO, Theodor W. Ästhetische Theorie. Frankfurt/M.: Suhrkamp, 1973.

ADORNO, Theodor W. Notas de literatura. Trad. C. Galeão, Rio de Janeiro: Tempo brasileiro, 1973a. 
ADORNO, Theodor W. Noten zur Literatur. Frankfurt/M.: Suhrkamp, 1981.

ADORNO, Theodor W. Ohne Leitbild. Frankfurt/M.: Suhrkamp, 1967.

ADORNO, Theodor W. Teoria Estética. Trad. Artur Mourão, Lisboa: Edições 70,1982 .

AUZÉPY, Marie-France. "La destruction de l'icône du Christ de la chalcé par Léon III : propagande ou réalité?", in: Byzantion vol. 60 (1990) p. 445-492.

BENJAMIN, Walter. Diário de Moscou. Trad. H. Herbol. São Paulo: Companhia das Letras, 1989.

BENJAMIN, Walter, Origem do drama trágico alemão, trad. João Barrento, Lisboa: Assírio Alvim, 2004.

BENJAMIN, Walter. Obras escolhidas, v. I, Magia e técnica, arte e política. Trad. S.P. Rouanet, revisão técnica Márcio Seligmann-Silva, São Paulo: Brasiliense, 2012a.

Benjamin, W. Rua de mão única. Tradução de Rubens Rodrigues Torres Filho e José Carlos Martins Barbosa, revisão técnica Márcio Seligmann-Silva, $6^{a}$. ed., São Paulo: Brasiliense, 2012b.

BENJAMIN, Walter. A obra de arte na era de sua reprodutibilidade técnica. Trad. Gabriel Valladão Silva, rev. técnica M. Seligmann-Silva, Porto Alegre: L\&PM, 2013.

BENJAMIN, Walter. Sobre o conceito de história. Edição crítica. Organização e tradução, Adalberto Müller e Márcio Seligmann-Silva, São Paulo: Alameda, 2020.

BESANÇON, Alain. A imagem proibida: uma história intelectual da iconoclastia. Bertrand Brasil, 1997.

Bíblia Sagrada Online, https://www.bibliaon.com

BONHEIM, Günther. Versuch zu zeigen, dass Adorno mit seiner Behauptung, nach Auschwitz lasse sich kein Gedicht mehr schreiben, recht hatte. Würzburg: Königshausen \& Neumann, 2002. 
DAMASCENO, São João. Contra aqueles que condenam as imagens sagradas. Contra a heresia iconoclasta. Curitiba: Editora Santo Anastásio, 2020.

DANEY, Serge, “Le travelling de Kapo”, in: Trafic, no 4, automne, 1992, pp. 5-19

DIDI-HUBERMAN, G. "Images Malgré tout”, in: Chéroux, Clément (org.). Mémoire des Camps. Photographies des Camps de Concentration et d'Extermination nazis (1933-1999). Paris: Marval, 2001.

DURAS, Marguerite. Hiroshima mon amour, Paris: Folio, 1960.

FREUD, S. O homem Moisés e a religião monoteísta, trad. Renato Zwick, Porto Alegre: L\&PM, 2014.

WAJCMAN, Gerard “De la croyance photographique”, in: Les Temps Modernes, mars-avril-mai 2001, no. 613.

João Paulo II. “Carta apostólica Duodecimum saeculum”, in: São João Damasceno, Contra aqueles que condenam as imagens sagradas. Contra a heresia iconoclasta, Curitiba: Editora Santo Anastásio, 2020, p. 12-22.

KILOMBA, Grada. Memórias da plantação: episódios de racismo cotidiano. Rio de Janeiro: Cobogó, 2019.

LACOUE-LABARTHE, Philippe; NANCY, Jean-Luc. O mito nazista. tradução Márcio Seligmann-Silva, São Paulo: Iluminuras, 2002.

LANZMANN, Claude. "Parler pour les morts", in: Le Monde des Débats maio 2000: ("L'art contre l'oubli")

LONGINO. "Sobre o sublime", in: Aristóteles, Horácio, Longino, A Poética Clássica, trad. J. Bruna, S. Paulo: Cultrix, 1988.

LOPES, Fabiana. "Rosana Paulino: o tempo do fazer e a prática do compartilhar", in: Rosana Paulino: a costura da memória. Curadoria Valéria Piccoli, Pedro Neri, textos Juliana Ribeiro da Silva Bevilaqua, Fabiana Lopes, Adriano Dolci Palma, São Paulo: Pinacoteca de São Paulo, 2018, p. 163-181.

NASCIMENTO, Abdias. O genocídio negro. Processo de um racismo mascarado. São Paulo: Perspectiva, 2016. 
NDIKUNG, Bonaventure Soh Bejeng. "Des-outrização como método (Leh zo, a me ken de za)". In: $21^{a}$ Bienal de Arte Contemporânea Sesc_Videobrasil: Comunidades imaginadas. São Paulo: Videobrasil; Edições Sesc, 2019. (Catálogo de exposição).

PEDROSA, Adriano; Carneiro, Amanda; Mesquita, André (orgs.). Histórias afro-atlânticas: [vol. 2] antologia. org. São Paulo: MASP, 2018.

PLATÃO. A República. (Da Justiça), tradução Edson Bini, Bauru: EDIPRO, 2006.

SCHOLEM, G. O nome de Deus, a teoria da linguagem, e outros estudos de Cabala e mística: Judaica II. São Paulo: Perspectiva, 1999.

SELIGMANN-SILVA, M. Decolonial, "Des-outrização: imaginando uma política pós-nacional e instituidora de novas subjetividades", in: 21 a Bienal de Arte Contemporânea Sesc_Videobrasil: Comunidades Imaginadas: Leituras. Organização: Luisa Duarte. São Paulo: Sesc: Associação Cultural Videobrasil, 2019, pp. 18-42.

SELIGMANN-SILVA, M. "Imagens precárias. Inscrições tênues da violência ditatorial no Brasil”, in: Estudos de Literatura Brasileira Contemporânea, n. 43, p. 13-34, (jan.jun./2014)

SELIGMANN-SILVA, Márcio (org.). História, Memória, Literatura. O testemunho na era das catástrofes. Campinas: Editora da UNICAMP, 2003.

STOICHITA, Victor I. Breve histoire de l'ombre. Genève: Droz, 2000.

YATES, Francis A.., The Art of Memory. Chicago: University of Chicago Press, 1966. 